\title{
Effect of Additional Sulfide and Thiosulfate on Corrosion of Q235 Carbon Steel in Alkaline Solutions
}

\author{
Bian Li Quan, ${ }^{1,2}$ Jun Qi Li, ${ }^{1,2}$ and Chao Yi Chen ${ }^{1,2}$ \\ ${ }^{1}$ College of Materials and Metallurgy, Guizhou University, Guiyang 550025, China \\ ${ }^{2}$ Guizhou Province Key Laboratory of Metallurgical Engineering and Process Energy Saving, Guiyang 550025, China
}

Correspondence should be addressed to Jun Qi Li; jqli@gzu.edu.cn

Received 19 April 2016; Revised 7 June 2016; Accepted 29 June 2016

Academic Editor: Flavio Deflorian

Copyright (C) 2016 Bian Li Quan et al. This is an open access article distributed under the Creative Commons Attribution License, which permits unrestricted use, distribution, and reproduction in any medium, provided the original work is properly cited.

\begin{abstract}
This paper investigated the effect of additional sulfide and thiosulfate on Q235 carbon steel corrosion in alkaline solutions. Weight loss method, scanning electron microscopy (SEM) equipped with EDS, X-ray photoelectron spectroscopy (XPS), and electrochemical measurements were used in this study to show the corrosion behavior and electrochemistry of Q235 carbon steel. Results indicate that the synergistic corrosion rate of Q235 carbon steel in alkaline solution containing sulfide and thiosulfate is larger than that of sulfide and thiosulfate alone, which could be due to redox reaction of sulfide and thiosulfate. The surface cracks and pitting characteristics of the specimens after corrosion were carefully examined and the corrosion products film is flake grains and defective. The main corrosion products of specimen induced by $\mathrm{S}^{2-}$ and $\mathrm{S}_{2} \mathrm{O}_{3}{ }^{2-}$ are $\mathrm{FeS}, \mathrm{FeS}_{2}, \mathrm{Fe}_{3} \mathrm{O}_{4}$, and FeOOH. The present study shows that the corrosion mechanism of $\mathrm{S}^{2-}$ and $\mathrm{S}_{2} \mathrm{O}_{3}{ }^{2-}$ is different for the corrosion of Q235 carbon steel.
\end{abstract}

\section{Introduction}

The use of high-sulfur bauxite makes Bayer solutions contain high content of $\mathrm{S}^{2-}$ in recent years. Therefore, in Bayer liquor of alumina extraction besides $\mathrm{Al}(\mathrm{OH})_{3}$ and caustic, other substances are impurities, including $\mathrm{Na}_{2} \mathrm{SO}_{3}$, $\mathrm{Na}_{2} \mathrm{SO}_{4}, \mathrm{Na}_{2} \mathrm{~S}_{2} \mathrm{O}_{3}, \mathrm{Na}_{2} \mathrm{~S}$ and other trace impurities, and so forth [1]. The content of four kinds of sulfide is $0.4 \mathrm{~g} \cdot \mathrm{L}^{-1}$, $0.8 \mathrm{~g} \cdot \mathrm{L}^{-1}, 1.2 \mathrm{~g} \cdot \mathrm{L}^{-1}$, and $1.6 \mathrm{~g} \cdot \mathrm{L}^{-1}$, respectively. Among them, $\mathrm{Na}_{2} \mathrm{~S}_{2} \mathrm{O}_{3}$ and $\mathrm{Na}_{2} \mathrm{~S}$ are corrosion activators to steel corrosion, which remain the most serious forms of metal failure [2, 3]. However, as an important equipment material, carbon steel has been widely used and plays a significant role in alumina industry which is used to dissolution equipment, dilution tank, Bayer mother liquor evaporation equipment, and so forth. With the progress of production, the corrosion of sulfides has been recognized as a serious problem, which results in a great economic loss and corrosion cracking and pitting of steel equipment has been experienced in different alumina industry. So, the study on corrosion of steel equipment and control is a very critical issue.
The mechanism of steel corrosion and formation of the passive film have been always studied by many scholars [4-6]. The role of sulfide in the highest concentrations of alkaline solution like white liquor has been studied on the corrosion behavior of carbon steel [7-9]. But in the higher concentrations of caustic solution sulfur-contained species like alumina industry the research of the role of sulfide on steel corrosion is too sparse and corrosion behavior of $16 \mathrm{MnR}$ low alloy steel in sulfide-containing Bayer solutions was researched by Xie and Chen [3]. The effect of $\mathrm{S}^{2-}$, $\mathrm{NaOH}$, and $\mathrm{Al}_{2} \mathrm{O}_{3}$ on the corrosion of $16 \mathrm{MnR}$ low alloy steel had been studied by polarization curves and electrochemical impedance spectroscopy (EIS). But the effect of the synergy effect of $\mathrm{S}^{2-}$ and $\mathrm{S}_{2} \mathrm{O}_{3}{ }^{2-}$ on Q235 carbon steel corrosion has not been discussed in detail.

Moreover, these corrosion experiments in literature have been performed using mostly conventional static stainless steel autoclave, dynamic and static immersion, and so on. The author will use the salt fog box to discuss corrosion of Q235 carbon steel in alkaline solutions containing sulfide and thiosulfate [10]. The aim is to use the accelerated corrosion of the salt fog box. 
TABLE 1: Chemical composition of Q235 carbon steel (wt.\%).

\begin{tabular}{lccccccc}
\hline Element & $\mathrm{C}$ & $\mathrm{Si}$ & $\mathrm{Mn}$ & $\mathrm{Cr}$ & $\mathrm{P}$ & $\mathrm{S}$ & $\mathrm{Fe}$ \\
\hline Content (\%) & 0.375 & 0.026 & 0.239 & 0.098 & 0.052 & 0.015 & $\mathrm{Bal}$ \\
\hline
\end{tabular}

The purpose of the study is to evaluate corrosion behavior of Q235 carbon steel through additional sulfide and thiosulfate to alkaline solutions and corrosion experiments are made in the salt fog box. The effect of $\mathrm{S}^{2-}$ and $\mathrm{S}_{2} \mathrm{O}_{3}{ }^{2-}$ on corrosion behavior of steel and mechanisms will be discussed in detail by employing weight loss measurements, scanning electron microscopy (SEM) equipped with an energy dispersive spectroscopy (EDS), X-ray photoelectron spectroscopy (XPS), and electrochemistry. The fundamental purposes are to gain the corrosion characteristics of Q235 carton steel in sulfur-containing alkaline solutions and to provide fundamental information for steel corrosion in sulfur-containing Bayer mother liquor and hence to provide insight into the understanding of the corrosion behavior and mechanism of Q235 carbon steel in alumina industry of the Southwest China.

\section{Experimental}

2.1. Specimens and Test Solutions. The chemical compositions (wt\%) of Q235 carbon steel used in this study are listed in Table 1 . The steel coupon was machined from steel with the $15 \mathrm{~mm} \times 15 \mathrm{~mm} \times 2.5 \mathrm{~mm}$ square type. Prior to experiment, the coupons were rinsed with distilled water, polished orderly with number 180, 240,360, and 600 silicon carbide paper and degreased with acetone, and finally dried with cold air.

The sulfur-containing alkaline solutions contained $115 \mathrm{~g} \cdot \mathrm{L}^{-1} \mathrm{NaOH}, 0,5 \mathrm{~g} \cdot \mathrm{L}^{-1} \mathrm{~S}^{2-}$, and $0,4,5 \mathrm{~g} \cdot \mathrm{L}^{-1} \mathrm{~S}_{2} \mathrm{O}_{3}{ }^{2-}$ at $328 \mathrm{~K}$. The solutions were prepared by dissolving $\mathrm{NaOH}$, $\mathrm{Na}_{2} \mathrm{~S} \cdot 9 \mathrm{H}_{2} \mathrm{O}$, and $\mathrm{Na}_{2} \mathrm{~S}_{2} \mathrm{O}_{3} \cdot 5 \mathrm{H}_{2} \mathrm{O}$ into $1000 \mathrm{~mL}$ of deionized water, respectively. The $\mathrm{pH}$ of the solutions is 14 by laboratory test, so $\mathrm{H}^{+}$can barely exist in such strong alkaline solution. All reagents are analytically pure.

2.2. The Corrosion Experiment. All of the corrosion experiments were carried out for $120 \mathrm{~h}$ at $328 \mathrm{~K}$ (maximum temperature of the salt fog box) in the salt fog box (GB/T 241952009). The samples were taken out one by one at regular intervals to analyze the corrosion behavior. The test solutions were supplemented daily. After being taken out from the salt fog box, these coupons were rinsed using distilled water and dried with cold air.

Prior to each corrosion experiment, the coupon was weighed to sensitivity level of $0.0001 \mathrm{~g}$ using an analytical balance $(\mathrm{AR} 1140 / \mathrm{C})$ for the original weight $\left(W_{1}\right)$ and its area $(S)$ was measured. Before weight loss measurements, the corrosion products were removed using the chemical products cleanup method (the $500 \mathrm{~mL}$ of hydrochloric acid + $500 \mathrm{~mL}$ deionized water $+10 \mathrm{~g}$ six methyl tetramine solutions) (GB/T 6074-1992) [11]. Finally, the sample was weighed again in order to obtain the final weight $\left(W_{2}\right)$.
The corrosion rate was calculated using weight loss measurement and the formula to calculate is given as

$$
R=8.76 \times 10^{4} \times\left(W_{1}-W_{2}\right) \times(S \times t \times D)^{-1},
$$

where $R$ is corrosion rate $(\mathrm{mm} / \mathrm{a}), W_{1}$ is the quality of the sample before the corrosion test $(\mathrm{g})$ with an accuracy of $\pm 0.0001 \mathrm{~g}, W_{2}$ is corrosion sample after the removal of corrosion products quality $(\mathrm{g})$ with an accuracy of $\pm 0.0001 \mathrm{~g}, S$ is the sample surface area $\left(\mathrm{cm}^{2}\right)$ with an accuracy of $0.01 \mathrm{~cm}^{2}$, $t$ is corrosion time (h) with an accuracy of $1 \mathrm{~h}$, and $D$ is the density of test steel $\left(\mathrm{g} / \mathrm{cm}^{3}\right)$.

2.3. Surface Analysis. The morphology and composition of Q235 carbon steel surface were observed with scanning electron microscopy (SEM) (SUPRA 40) and energy dispersive spectroscopy (EDS) (AZ tec.).

The composition of the passive films was analyzed by means of PHI Quantum 2000 Scanning ESCA Microprobe Xrays photoelectron spectrometer (XPS). Monochromatized $\mathrm{Al} \mathrm{Ka}$ radiation $(1486.6 \mathrm{eV})$ was used as the excitation source. After being exposed to the solutions for different concentrations of $\mathrm{S}^{2-}$ and $\mathrm{S}_{2} \mathrm{O}_{3}{ }^{2-}$, the sample was dried and transferred to the XPS instrument for analysis. The binding energy values were calibrated with reference to the $C 1$ s peak at $284.8 \mathrm{eV}$. The data processing and Photoelectron analytical peak would be parsed using Multipeak 8.0; the narrow scan spectra were fitted with XPSPeak 4.1 software.

2.4. Electrochemical Measurement. Electrochemical testing was carried out in a conventional three-electrode cell at $338 \mathrm{~K}$. The temperature of $338 \mathrm{~K}$ is to simulate the alumina dilution process. Using a saturated calomel electrode (SCE) as the reference electrode, platinum electrodes are auxiliary electrode and Q235 steel as working electrode. Before electrochemical experiment the sample was immersed for $120 \mathrm{~h}$ in the solutions. The work area of Q235 steel is $2.25 \mathrm{~cm}^{2}$, nonworking parts sealed with epoxy resin. The cell was placed in a water bath to achieve the test temperature. Potentiodynamic polarization curves measurements were performed at a potential scan rate of $1 \mathrm{mV} / \mathrm{s}$. The potential range was from $-1.5 \mathrm{~V}$ to $0.5 \mathrm{~V}$. The EIS measurements were carried out at OCP over the frequency from $100 \mathrm{kHz}$ to $10 \mathrm{mHz}$ by 5 points per decade. All potentials reported in this paper were measured with respect to the SCE. All the tests were repeated to obtain reproducibility of results.

\section{Results and Discussion}

3.1. Corrosion Rate. Weight loss measurement is a more reliable way to get the corrosion rate compared with other methods [12]. Table 2 shows the corrosion rate (mm/a) of Q235 carbon steel based on weightlessness corrosion experiment in the alkaline solutions with different concentrations of $\mathrm{S}^{2-}$ and $\mathrm{S}_{2} \mathrm{O}_{3}{ }^{2-}$ at $328 \mathrm{~K}$. The corrosion rate of steel increased significantly in the presence of $\mathrm{S}_{2} \mathrm{O}_{3}{ }^{2-}$ or $\mathrm{S}^{2-}$, and the corrosion rate much increased when it is synergy corrosion. Thus it can be seen that $\mathrm{S}^{2-}$ and $\mathrm{S}_{2} \mathrm{O}_{3}{ }^{2-}$ were corrosion 
TABLE 2: Corrosion rate of Q235 carbon steel in alkaline solutions.

\begin{tabular}{|c|c|c|}
\hline $\begin{array}{l}\mathrm{S}^{2-} \text { concentration } \\
\left(\mathrm{g} \cdot \mathrm{L}^{-1}\right)\end{array}$ & $\begin{array}{c}\mathrm{S}_{2} \mathrm{O}_{3}{ }^{2-} \text { concentration } \\
\left(\mathrm{g} \cdot \mathrm{L}^{-1}\right)\end{array}$ & $\begin{array}{l}\text { Corrosion } \\
\text { rate }(\mathrm{mm} / \mathrm{a})\end{array}$ \\
\hline 0 & 0 & 0.01 \\
\hline 0 & 4 & 0.03 \\
\hline 5 & 0 & 0.08 \\
\hline 5 & 4 & 0.18 \\
\hline 5 & 5 & 0.10 \\
\hline
\end{tabular}

activators for Q235 carbon steel when they are separate in alkaline solution; however, when $\mathrm{S}^{2-}$ and $\mathrm{S}_{2} \mathrm{O}_{3}{ }^{2-}$ exist altogether, the reduction reaction of $\mathrm{S}_{2} \mathrm{O}_{3}{ }^{2-}$ accelerates iron loss of electrons and the hydrolysis of $\mathrm{S}^{2-}$ was also inhibited, so the corrosion is accelerated. The reduction reaction of $\mathrm{S}_{2} \mathrm{O}_{3}{ }^{2-}$ could be described as follows:

$$
\begin{aligned}
\mathrm{S}_{2} \mathrm{O}_{3}{ }^{2-}+5 \mathrm{H}_{2} \mathrm{O}+8 \mathrm{e}^{-} & =2 \mathrm{HS}^{-}+8 \mathrm{OH}^{-} \\
\mathrm{S}^{2-}+\mathrm{H}_{2} \mathrm{O} & =\mathrm{HS}^{-}+\mathrm{OH}^{-}
\end{aligned}
$$

When the concentration of $\mathrm{S}_{2} \mathrm{O}_{3}{ }^{2-}$ is $5 \mathrm{~g} \cdot \mathrm{L}^{-1}$, the loss of electrons of $\mathrm{S}^{2-}$ and $\mathrm{S}_{2} \mathrm{O}_{3}{ }^{2-}$ inhibits the iron loss of electrons. So, the corrosion rate decreases as follows:

$$
\begin{aligned}
2 \mathrm{~S}^{2-} & +\mathrm{S}_{2} \mathrm{O}_{3}{ }^{2-}+6 \mathrm{OH}^{-} \\
& =\mathrm{S}_{2}{ }^{2-}+2 \mathrm{SO}_{3}{ }^{2-}+3 \mathrm{H}_{2} \mathrm{O}+6 \mathrm{e}^{-}
\end{aligned}
$$

This is consistent with what was previously reported that thiosulfate is corrosive activator [3] and inconsistent with the conclusions of Xie et al. [13]. So, whether or not the effect of thiosulfate on corrosion of Q235 carbon steel is to accelerate or hinder which mainly depends on the concentration of sulfide when they are synergy corrosion [14]. Besides, in strong alkaline medium, the solutions have a lot of $\mathrm{OH}^{-}$and hinder the secondary hydrolysis reaction of $\mathrm{S}^{2-}$ ion; therefore, the concentration of $\mathrm{HS}^{-}$is higher, is helpful to generate the sulfide film, and thus decreases the corrosion rate of Q235 carbon steel in the initial stage of corrosion [15].

3.2. Surface Morphology and Composition. Figure 1 shows SEM images of corrosion products film on the specimen surfaces and the corresponding EDS in alkaline solutions with different concentrations $\mathrm{S}^{2-}$ and $\mathrm{S}_{2} \mathrm{O}_{3}{ }^{2-}$ at $328 \mathrm{~K}$ after 120 hours of corrosion. It can be seen that the corrosion products cover unevenly the surface.

As shown in Figure 1, a large amount of corrosion is formed on steel surface with the additives of different concentrations $\mathrm{S}^{2-}$ and $\mathrm{S}_{2} \mathrm{O}_{3}{ }^{2-}$; the corrosion is the most serious in the presence of $\mathrm{S}^{2-}$ (Figure $1(\mathrm{c})$ ) and the presence of $\mathrm{S}^{2-}$ and $\mathrm{S}_{2} \mathrm{O}_{3}{ }^{2-}$ (Figures $1(\mathrm{~d})$ and $1(\mathrm{e})$ ) [16]. As can be seen from Figures 1(c), 1(d), and 1(e), there are selective corrosion and pitting with carbon steel. The corrosion surface with a loose and porous structure is easy to fall off, which cannot protect the metal matrix. The corrosion of Q235 carbon steel is slight in pure alkaline solution and steel surface has some
TABLE 3: Element distributions of corrosion products with different concentrations of sulfide and thiosulfate at $328 \mathrm{~K}$ (wt.\%).

\begin{tabular}{lccc}
\hline Concentrations of sulfide and thiosulfate & $\mathrm{O}$ & $\mathrm{S}$ & $\mathrm{Fe}$ \\
\hline $0 \mathrm{~g} \cdot \mathrm{L}^{-1} \mathrm{~S}^{2-}$ and $4 \mathrm{~g} \cdot \mathrm{L}^{-1} \mathrm{~S}_{2} \mathrm{O}_{3}{ }^{2-}$ & 31.43 & 4.55 & 64.02 \\
$5 \mathrm{~g} \cdot \mathrm{L}^{-1} \mathrm{~S}^{2-}$ and $0 \mathrm{~g} \cdot \mathrm{L}^{-1} \mathrm{~S}_{2} \mathrm{O}_{3}{ }^{2-}$ & 7.67 & 30.28 & 62.05 \\
$5 \mathrm{~g} \cdot \mathrm{L}^{-1} \mathrm{~S}^{2-}$ and $4 \mathrm{~g} \cdot \mathrm{L}^{-1} \mathrm{~S}_{2} \mathrm{O}_{3}{ }^{2-}$ & 8.60 & 17.61 & 73.79 \\
$5 \mathrm{~g} \cdot \mathrm{L}^{-1} \mathrm{~S}^{2-}$ and $5 \mathrm{~g} \cdot \mathrm{L}^{-1} \mathrm{~S}_{2} \mathrm{O}_{3}{ }^{2-}$ & 2.78 & 7.89 & 89.32 \\
\hline
\end{tabular}

defects and scratches (Figure 1(a)). Therefore, it is thought that the corrosion of Q235 carbon steel preferentially takes place in defects and scratches, mainly caused by polishing [17], whose surface roughness and surface residual have resulted in the faster corrosion rate.

Table 3 lists the distribution of elements with Q235 carbon steel for different concentrations of $\mathrm{S}^{2-}$ and $\mathrm{S}_{2} \mathrm{O}_{3}{ }^{2-}$ in solutions at $328 \mathrm{~K}$. From Table 3 it can be seen that the oxygen content is largest in the absence of $\mathrm{S}^{2-}$ and the sulfur content is largest in the absence of $\mathrm{S}_{2} \mathrm{O}_{3}{ }^{2-}$, which decreases later with the concentration of $\mathrm{S}_{2} \mathrm{O}_{3}{ }^{2-}$. The results show that the oxidation film is generated at the steel surface mainly in the absence of $\mathrm{S}^{2-}$, and the corrosion products are sulfide in the absence of $\mathrm{S}_{2} \mathrm{O}_{3}{ }^{2-}$. The compactness and stability of oxidation film are higher than those of sulfide. Results of EDS indicate that the corrosion mechanism of Q235 carbon steel $\mathrm{S}^{2-}$ and $\mathrm{S}_{2} \mathrm{O}_{3}{ }^{2-}$ is different.

3.3. Potentiodynamic Polarization Curves. Figure 2 is the potentiodynamic polarization curves of Q235 carbon steel in alkaline solutions with different concentrations of $\mathrm{S}^{2-}$ and $\mathrm{S}_{2} \mathrm{O}_{3}{ }^{2-}$ at $338 \mathrm{~K}$. As can be seen from Figure 2, the anodic process exhibits active-passive-transpassive behaviors, which indicates that the surface of specimen formed compact corrosion products film at later stage and the anodic iron dissolution and the transformation of iron compounds. This could be due to the fact that the corrosion process involved transformation of corrosion products, always maintaining the surface active [18]. In alkaline solutions regardless of the concentrations of $\mathrm{S}^{2-}$ and $\mathrm{S}_{2} \mathrm{O}_{3}{ }^{2-}, \mathrm{Q} 235$ carbon steel exhibits corrosion potential $\left(E_{\text {corr }}\right)$ near $-1.20 \mathrm{~V}$ versus SCE in the active state. At the potentials $-1.0 \mathrm{~V}$ versus SCE, the curves exhibit a humped shape, revealing at least two reactions including one for the exposed steel anodically dissolved into the electrolyte to form $\mathrm{FeO}_{2}{ }^{-}$ions and another one attributed to the oxidation of $\mathrm{S}_{2} \mathrm{O}_{3}{ }^{2-}$ to higher forms, as described by Zou and Chin [19].

The determination of corrosion parameters $\left(E_{\text {corr }}, \beta_{a}\right.$, $\beta_{c}, i_{\text {corr }}, i_{c}$, and $R_{p}$ ) could provide more information about the overall corrosion process. Table 4 shows the corrosion potentials $\left(E_{\text {corr }}\right)$, Tafel slopes $\left(\beta_{a}\right.$ and $\beta_{c}$ represent anodic and cathodic, resp.), corrosion currents $\left(i_{\text {corr }}\right)$, critical current density $\left(i_{c}\right)$, and polarization resistance $\left(R_{p}\right)$ obtained from Tafel fitting of the polarization curves data. The higher critical current density suggests that corrosion of steel increases. When $\mathrm{S}^{2-}$ concentration is $5 \mathrm{~g} \cdot \mathrm{L}^{-1}$, the presence of $\mathrm{S}_{2} \mathrm{O}_{3}{ }^{2-}$ caused a considerable increase in the critical current density 
TABLE 4: Electrochemical parameters fitted from the potentiodynamic polarization curves of Q235 carbon steel.

\begin{tabular}{lcccccc}
\hline Concentration $\left(\mathrm{g} \cdot \mathrm{L}^{-1}\right)$ & $E_{\text {corr }}(\mathrm{mV})$ & $i_{\text {corr }}\left(\mu \mathrm{A} / \mathrm{cm}^{2}\right)$ & $\beta_{a}(\mathrm{mV})$ & $\beta_{c}(\mathrm{mV})$ & $i_{c}\left(\mathrm{~mA} / \mathrm{cm}^{2}\right)$ & $R_{p}(\mathrm{Ohm})$ \\
\hline $5 \mathrm{~g} \cdot \mathrm{L}^{-1} \mathrm{~S}^{2-}+5 \mathrm{~g} \cdot \mathrm{L}^{-1} \mathrm{~S}_{2} \mathrm{O}_{3}{ }^{2-}$ & -1155 & 365 & 228.0 & 122.0 & 2.4 & 31.1 \\
$5 \mathrm{~g} \cdot \mathrm{L}^{-1} \mathrm{~S}^{2-}+4 \mathrm{~g} \cdot \mathrm{L}^{-1} \mathrm{~S}_{2} \mathrm{O}_{3}{ }^{2-}$ & -1179 & 792 & 112.6 & 119.0 & 10.4 & 14.6 \\
$5 \mathrm{~g} \cdot \mathrm{L}^{-1} \mathrm{~S}^{2-}+0 \mathrm{~g} \cdot \mathrm{L}^{-1} \mathrm{~S}_{2} \mathrm{O}_{3}{ }^{2-}$ & -1242 & 372 & 172.8 & 116.9 & 2.1 & 31.7 \\
$0 \mathrm{~g} \cdot \mathrm{L}^{-1} \mathrm{~S}^{2-}+4 \mathrm{~g} \cdot \mathrm{L}^{-1} \mathrm{~S}_{2} \mathrm{O}_{3}{ }^{2-}$ & -1167 & 14.5 & 132.2 & 135.3 & 0.8 & 1104 \\
\hline
\end{tabular}
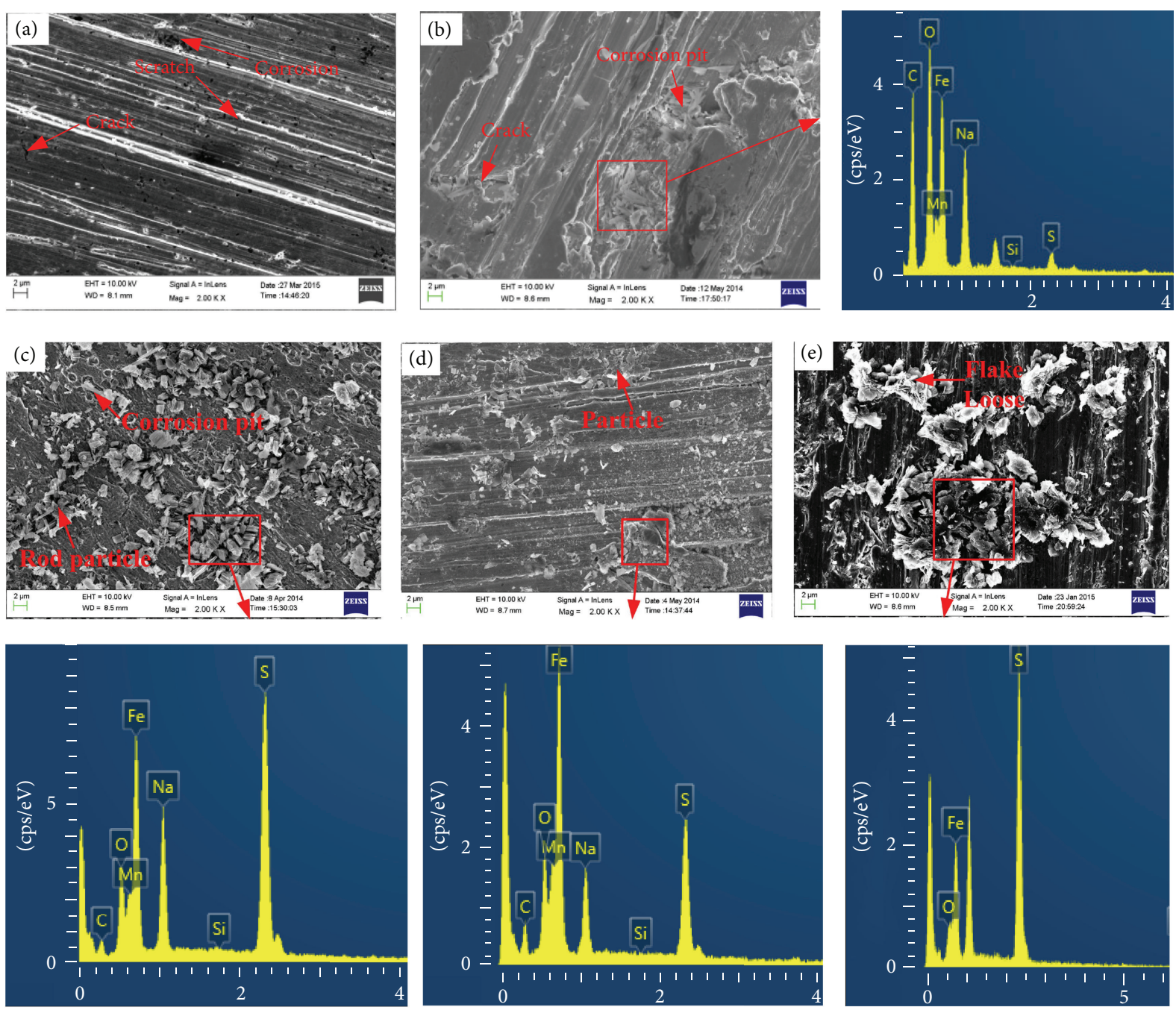

FIGURE 1: Morphologies (SEM) of Q235 carbon steel in alkaline solutions with different concentrations of $\mathrm{S}^{2-}$ and $\mathrm{S}_{2} \mathrm{O}_{3}{ }^{2-}$ at $328 \mathrm{~K}$. (a) $0 \mathrm{~g} \cdot \mathrm{L}^{-1}$ $\mathrm{S}^{2-}$ and $0 \mathrm{~g} \cdot \mathrm{L}^{-1} \mathrm{~S}_{2} \mathrm{O}_{3}{ }^{2-}$, (b) $0 \mathrm{~g} \cdot \mathrm{L}^{-1} \mathrm{~S}^{2-}$ and $4 \mathrm{~g} \cdot \mathrm{L}^{-1} \mathrm{~S}_{2} \mathrm{O}_{3}{ }^{2-}$, (c) $5 \mathrm{~g} \cdot \mathrm{L}^{-1} \mathrm{~S}^{2-}$ and $0 \mathrm{~g} \cdot \mathrm{L}^{-1} \mathrm{~S}_{2} \mathrm{O}_{3}{ }^{2-}$, (d) $5 \mathrm{~g} \cdot \mathrm{L}^{-1} \mathrm{~S}^{2-}$ and $4 \mathrm{~g} \cdot \mathrm{L}^{-1} \mathrm{~S}_{2} \mathrm{O}_{3}{ }^{2-}$, (e) $5 \mathrm{~g} \cdot \mathrm{L}^{-1} \mathrm{~S}^{2-}$ and $5 \mathrm{~g} \cdot \mathrm{L}^{-1} \mathrm{~S}_{2} \mathrm{O}_{3}{ }^{2-}$.

(Table 4) which shows that $\mathrm{S}_{2} \mathrm{O}_{3}{ }^{2-}$ is activator; however, the increase of $\mathrm{S}_{2} \mathrm{O}_{3}{ }^{2-}$ concentration decelerated the corrosion of Q235 carbon steel when the concentration of $\mathrm{S}^{2-}$ is $5 \mathrm{~g} \cdot \mathrm{L}^{-1}$ [14], reflecting that $S^{2-}$ played a more important role in the corrosion of Q235 carbon steel. Anodic Tafel slopes, $\beta_{c}$ (Table 4 ), in $\mathrm{S}^{2-}$-containing solutions are very similar (about $120 \mathrm{mV}$ ), regardless of the concentration of $\mathrm{S}_{2} \mathrm{O}_{3}{ }^{2-}$.
However, the slopes of the anodic branch, $\beta_{a}$ (Table 4), are considerably dependent on the concentration of $\mathrm{S}_{2} \mathrm{O}_{3}{ }^{2-}$. This fact, along with higher values of these slopes compared with those from the anodic branch, indicates the complex nature of the oxidation process. The change of $i_{c}$ is the opposite trend to the change of $R_{p}$ (Table 4 ). The shape of cathodic polarization curve of $\mathrm{S}_{2} \mathrm{O}_{3}{ }^{2-}$ is different from $\mathrm{S}^{2-}$, which shows that the 
TABLE 5: EIS fitting results of Q235 steel in alkaline solutions with different concentrations of $\mathrm{S}^{2-}$ and $\mathrm{S}_{2} \mathrm{O}_{3}{ }^{2-}$.

\begin{tabular}{lcccccccc}
\hline Concentration $/ \mathrm{g} \cdot \mathrm{L}^{-1}$ & $R_{s} / \Omega \cdot \mathrm{cm}^{2}$ & $R_{\mathrm{ct}} / \Omega \cdot \mathrm{cm}^{2}$ & $\mathrm{CPE}_{\mathrm{dl}}\left(Y_{0}\right) / \Omega^{-1} \cdot \mathrm{cm}^{-2} \cdot \mathrm{s}^{-n}$ & $n_{1}$ & $R_{f} / \Omega \cdot \mathrm{cm}^{2}$ & $\mathrm{CPE}_{f}\left(Y_{0}\right) / \Omega^{-1} \cdot \mathrm{cm}^{-2} \cdot \mathrm{s}^{-n}$ & $n_{2}$ & $R^{2}$ \\
\hline $5 \mathrm{~g} \cdot \mathrm{L}^{-1} \mathrm{~S}^{2-}+5 \mathrm{~g} \cdot \mathrm{L}^{-1} \mathrm{~S}_{2} \mathrm{O}_{3}{ }^{2-}$ & 0.441 & 67.48 & 0.00132 & 0.88 & 12134 & 0.0074 & 0.52 & $1 e-20$ \\
$5 \mathrm{~g} \cdot \mathrm{L}^{-1} \mathrm{~S}^{2-}+4 \mathrm{~g} \cdot \mathrm{L}^{-1} \mathrm{~S}_{2} \mathrm{O}_{3}{ }^{2-}$ & 0.288 & 1.235 & 0.093 & 0.89 & 48.46 & 0.173 & 0.61 & $1 e-20$ \\
$5 \mathrm{~g} \cdot \mathrm{L}^{-1} \mathrm{~S}^{2-}+0 \mathrm{~g} \cdot \mathrm{L}^{-1} \mathrm{~S}_{2} \mathrm{O}_{3}{ }^{2-}$ & 0.743 & 78.21 & 0.26 & 0.99 & 105.4 & 0.149 & 0.92 & $1 e-20$ \\
$0 \mathrm{~g} \cdot \mathrm{L}^{-1} \mathrm{~S}^{2-}+4 \mathrm{~g} \cdot \mathrm{L}^{-1} \mathrm{~S}_{2} \mathrm{O}_{3}{ }^{2-}$ & 1.969 & 4234 & 0.0002 & 0.97 & 77719 & 0.00002 & 0.62 & $1 e-20$ \\
\hline
\end{tabular}

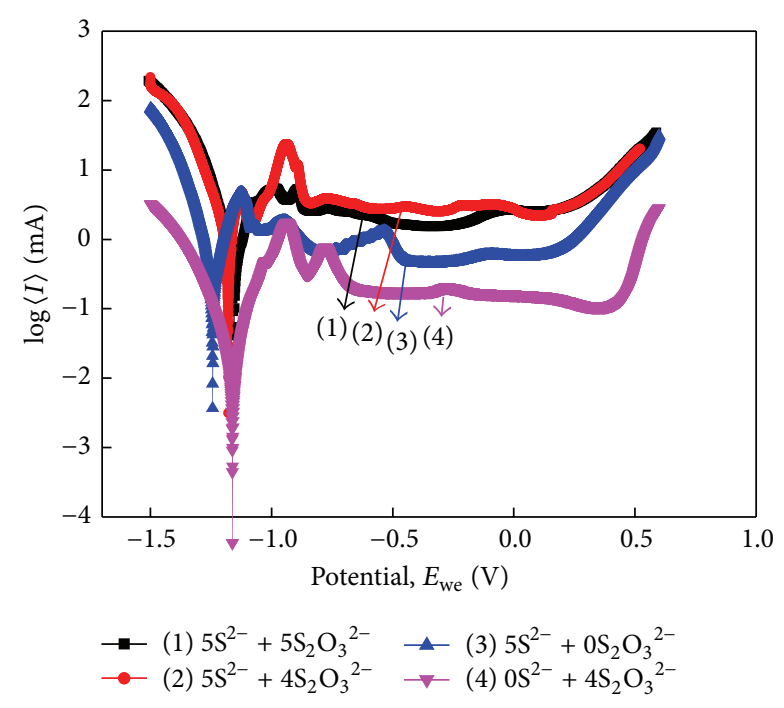

FIGURE 2: Potentiodynamic polarization curves of Q235 carbon steel in solutions with different concentrations of $\mathrm{S}^{2-}$ and $\mathrm{S}_{2} \mathrm{O}_{3}{ }^{2-}$ at $338 \mathrm{~K}$.

cathodic reactions of $\mathrm{S}^{2-}$ and $\mathrm{S}_{2} \mathrm{O}_{3}{ }^{2-}$ are different for the corrosion of Q235 carbon steel, consistent with the EDS findings.

3.4. Electrochemical Impedance Spectroscopy. Typical Nyquist and Bode plots of Q235 carbon steel after passivation for $120 \mathrm{~h}$ in alkaline solutions with different concentrations of $\mathrm{S}^{2-}$ and $\mathrm{S}_{2} \mathrm{O}_{3}{ }^{2-}$ at $338 \mathrm{~K}$ at the open-circuit potential (OCP) are illustrated in Figure 3. Nyquist plots in Figure 3 indicate that the overall impedance of steel in alkaline solution without $\mathrm{S}^{2-}$ is the largest, but then it decreases in the presence of $\mathrm{S}^{2-}$, suggesting an activation of the corrosion processes, as expected in the presence of sulfides [2]. In the presence of $\mathrm{S}^{2-}$, the overall impedance reduces when the $\mathrm{S}_{2} \mathrm{O}_{3}{ }^{2-}$ concentration increases from 0 to $4 \mathrm{~g} \cdot \mathrm{L}^{-1}$, after increasing the $\mathrm{S}_{2} \mathrm{O}_{3}{ }^{2-}$ concentration being $5 \mathrm{~g} \cdot \mathrm{L}^{-1}$, and makes the surface more sensitive to $\mathrm{S}^{2-}$ and $\mathrm{S}_{2} \mathrm{O}_{3}{ }^{2-}$ attack. These data of EIS testes in Figure 3 further support the results from potentiodynamic polarization curves in Figure 2. Deconvolution of the phase angle curves of Bode plots in Figure 3 indicate that two overlapped time constants are found for Q235 carbon steel in solutions in the presence of $\mathrm{S}^{2-}$ and $\mathrm{S}_{2} \mathrm{O}_{3}{ }^{2-}$.

The experimental data was then fitted by $Z$-View, and the results are shown in Figure 3, which is in accordance with some references [20, 21]. As shown, the fitted curves are in good agreement with corresponding experimental data. To further understand the processes and mechanisms of Q235 carbon steel corrosion, electrical equivalent circuit was constructed (see Figure 4). In the model, $R_{s}$ denotes the resistance between the working electrode and reference electrode, $R_{f}$ and $Q_{f}$ represent, respectively, the resistance and capacitance of the oxidation film or corrosion products film, and $R_{\mathrm{ct}}$ and $Q_{\mathrm{dl}}$ are the charge transfer resistance and constant phase element (CPE), respectively. The reason of $Q$ for capacitors in analysis of impedance spectra is that the passive film is not considered as a homogeneous layer but rather as a defective layer. The impedance of $Q$ is defined as

$$
Z_{\mathrm{Q}}=Y_{0}^{-1}(j \omega)^{-n},
$$

where $Y_{0}$ is the admittance, $\omega$ is angular frequency in $\mathrm{rad} / \mathrm{s}$, $j^{2}=(-1)$, and $n$ is an exponential term which always lies between 0.5 and 1.0. When $n=1$, the CPE describes an ideal capacitor. When $n=0.5$, the CPE represents a Warburg impedance with diffusional character. For $0.5<n<$ 1 , the CPE describes a distribution of dielectric relaxation times in frequency space. From the fitted values of electrical equivalent circuits (listed in Table 5), one can find that after the corrosion product film is generated, $n_{1}$ and $n_{2}$ decreases with the concentration of $\mathrm{S}_{2} \mathrm{O}_{3}{ }^{2-}$, suggesting that the corrosion of the steel became more and more serious [22]. The change of $R_{f}$ also corresponds to the change of polarization results (Table 4). Equivalent circuit mode shows that passive film does not completely cover the metal surface, which is due to surface roughness and other reasons that can cause the dispersion effect. The passive film is not a uniform layer, but a porous film of characteristic. Results are consistent with SEM-EDS analysis.

3.5. Surface Analysis of Specimens by XPS. Figure 5 shows the decomposition of peaks for $\mathrm{Fe} 2 \mathrm{p} 3, \mathrm{~S} 2 \mathrm{p}$, and O1s of the passive films formed on Q235 carbon steel. Peak decompositions of Fe2p3, S2p, and O1s core level spectra are in agreement with published results [23-25]. In the O1s spectrum, a broad peak and two narrow peaks are observed at about $528-536 \mathrm{eV}$ in the solutions. The O1s spectrum can be curve-fitted with two peaks. The peak at $529.92 \mathrm{eV}$ is attributed to $\mathrm{O}^{2-}$ in oxides. The peak at $531.5 \mathrm{eV}$ can be attributed to oxygen in $\mathrm{FeOOH}$. The Fe2p 3 spectrum can be curve-fitted with four peaks. The peaks at 706.91, 708.19, 710.49, and $712.82 \mathrm{eV}$ correspond to $\mathrm{FeS}_{2}, \mathrm{Fe}_{3} \mathrm{O}_{4}$, and $\mathrm{FeS}$. The formation of a stable layer $\left(\mathrm{Fe}_{3} \mathrm{O}_{4}\right)$, which can inhibit the diffusion of corrosive species, will be 


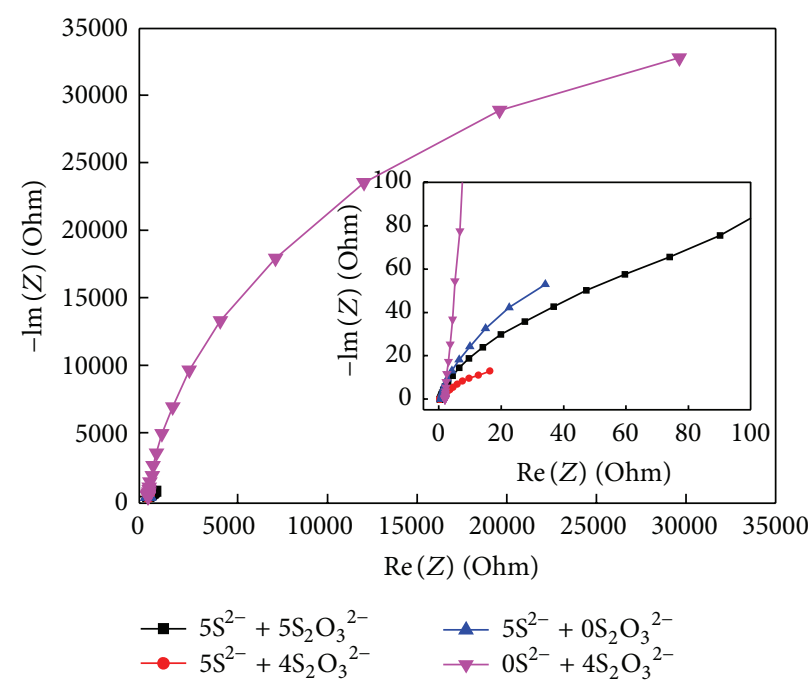

(a)

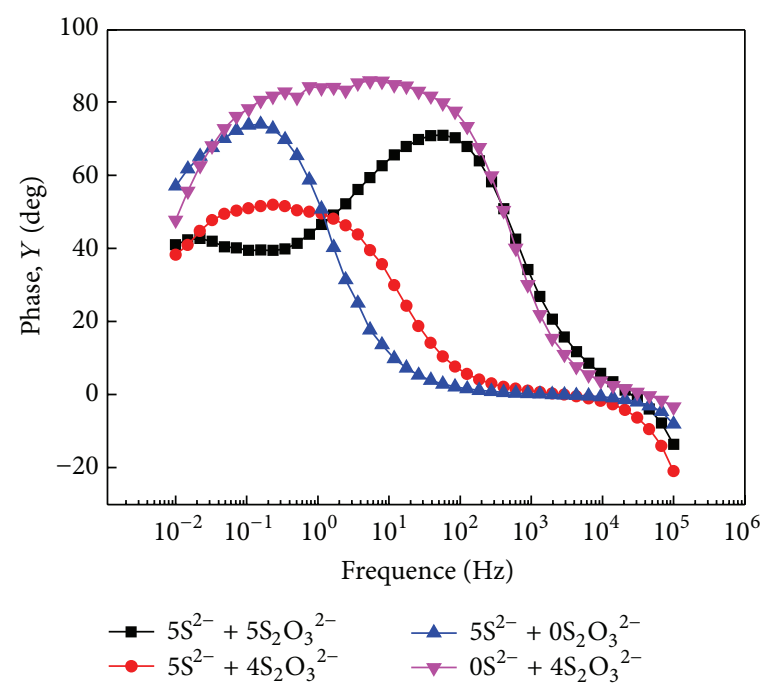

(b)

FIGURE 3: EIS of Q235 carbon steel in alkaline solutions with different concentrations of $\mathrm{S}^{2-}$ and $\mathrm{S}_{2} \mathrm{O}_{3}{ }^{2-}$ solutions. (a) Nyquist plot and amplificatory plot and (b) Bode plot (phase angle versus frequency).

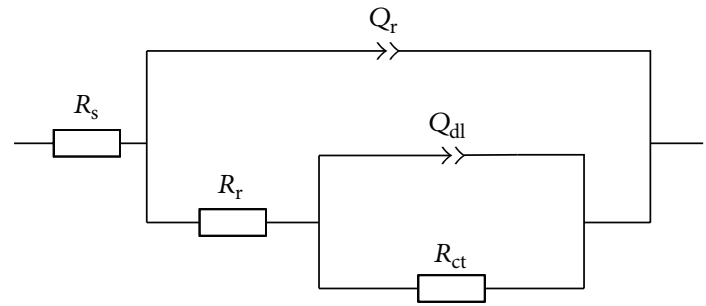

Figure 4: Equivalent circuit for EIS of Q235 steels in alkaline.

beneficial to improve the corrosion resistance of specimen. The S2p spectrum can be curve-fitted with four peaks. The peaks at 163.02, 164.17, 161.84, and $162.99 \mathrm{eV}$ correspond to $\mathrm{FeS}_{2}$ and FeS. Table 6 shows XPS peak position and peak result analysis of the corrosion scale of Q235 carbon steel, which indicates that the corrosion scale of Q235 carbon steel mainly consisted of $\mathrm{FeS}, \mathrm{FeS}_{2}, \mathrm{Fe}_{3} \mathrm{O}_{4}$, and $\mathrm{FeOOH}$.

\section{Conclusions}

The corrosion behavior of Q235 carbon steel was investigated using weight loss measurements, SEM-EDS, XPS, and electrochemistry in alkaline solutions adding sulfide and thiosulfate at $328 \mathrm{~K}$. S ${ }^{2-}$ and $\mathrm{S}_{2} \mathrm{O}_{3}{ }^{2-}$ are corrosion activators for Q235 carbon steel when they are separate in alkaline solution. A large number of granular corrosion products accumulated in the defects or the scratches, and severe selective corrosion and pitting corrosion on Q235 carbon steel surfaces were observed. The XPS analysis results indicated that the main corrosion products of specimen induced by $\mathrm{S}^{2-}$ and $\mathrm{S}_{2} \mathrm{O}_{3}{ }^{2-}$ were $\mathrm{FeS}, \mathrm{FeS}_{2}, \mathrm{Fe}_{3} \mathrm{O}_{4}$, and $\mathrm{FeOOH}$. The corrosion products film of Q235 carbon steel is not a uniform layer, and the
TABLE 6: XPS peak position and peak result of the corrosion scale of Q235 carbon steel.

\begin{tabular}{|c|c|c|c|c|}
\hline \multicolumn{2}{|c|}{ Elements } & \multirow{2}{*}{$\begin{array}{c}\text { Binging } \\
\text { energy }(\mathrm{eV})\end{array}$} & \multirow{2}{*}{$\begin{array}{c}\text { Peaks } \\
\mathrm{FeS}_{2}, \mathrm{III}\end{array}$} & \multirow{2}{*}{$\begin{array}{c}\text { Peaks } \\
\text { intensity (\%) } \\
18.72\end{array}$} \\
\hline \multirow{4}{*}{$\mathrm{Fe}$} & \multirow{4}{*}{$2 \mathrm{p} 3$} & & & \\
\hline & & 708.19 & $\mathrm{Fe}_{3} \mathrm{O}_{4}, \mathrm{II}$ & 12.54 \\
\hline & & 710.49 & FeS, I & 42.62 \\
\hline & & 712.82 & FeS, I & 26.12 \\
\hline \multirow{4}{*}{$S$} & \multirow{2}{*}{$2 \mathrm{p} 1$} & 163.02 & FeS, I & 22.63 \\
\hline & & 164.17 & $\mathrm{FeS}_{2}$, III & 10.70 \\
\hline & \multirow{2}{*}{$2 \mathrm{p} 3$} & 161.84 & $\mathrm{FeS}, \mathrm{I}$ & 45.26 \\
\hline & & 162.99 & $\mathrm{FeS}_{2}$, III & 21.40 \\
\hline \multirow{3}{*}{$\mathrm{O}$} & \multirow{3}{*}{ 1s } & 529.92 & $\mathrm{Fe}_{3} \mathrm{O}_{4}, \mathrm{II}$ & 21.64 \\
\hline & & 531.50 & FeOOH, IV & 67.65 \\
\hline & & 535.16 & & 10.51 \\
\hline
\end{tabular}

corrosion mechanism of $\mathrm{S}^{2-}$ and $\mathrm{S}_{2} \mathrm{O}_{3}{ }^{2-}$ is different for the corrosion of Q235 carbon steel. The $R_{f}$ values strongly depended on the stability and compactness of the corrosion products film of steel surface in sulfur-containing alkaline solutions. This paper studied only a production process of alumina industry, and the corrosion of the other aspects still needs further discussion.

\section{Competing Interests}

The authors declare that they have no competing interests. 


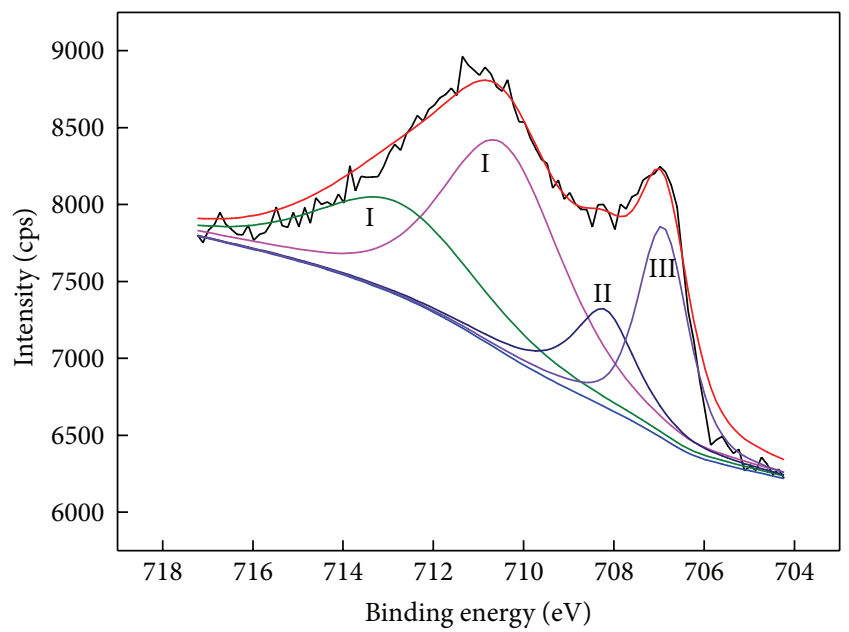

(a)

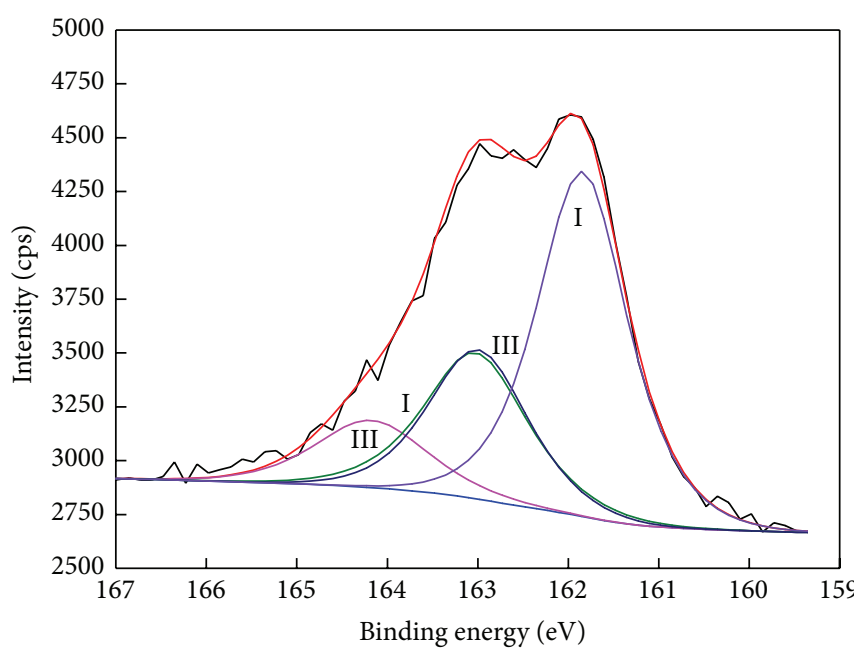

(b)

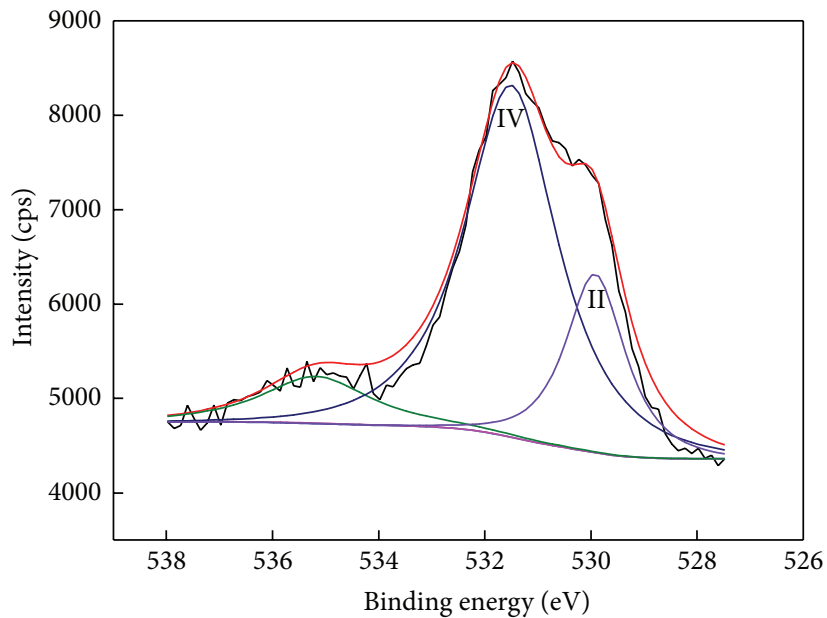

(c)

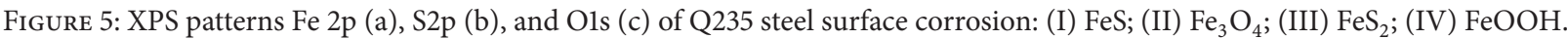

\section{Acknowledgments}

This work was supported by the National Natured Science Foundation of China (Grant nos. 51264006, 51474079, and 51574095), Guizhou Natural Science Fund ([2014]7609 and [2015]7652), Project supported by Guizhou Education Department (KY [2015]334), NSFC (51264006, 51474079, and 51574095), Guizhou Natural Science Fund ([2014]7609 and [2015]7652), and 125 Key Fund of Education Department of Guizhou Province (2012)0002.

\section{References}

[1] S. W. Bi, Alumina Production Process, Chemical Industry Press, Beijing, China, 2006.

[2] A. Bhattacharya and P. M. Singh, "Electrochemical behaviour of duplex stainless steels in caustic environment," Corrosion Science, vol. 53, no. 1, pp. 71-81, 2011.
[3] Q. Xie and W. Chen, "Corrosion behavior of 16Mn low alloy steel in sulfide-containing Bayer solutions," Corrosion Science, vol. 86, pp. 252-260, 2014.

[4] R. E. Melchers, "Mathematical modelling of the diffusion controlled phase in marine immersion corrosion of mild steel," Corrosion Science, vol. 45, no. 5, pp. 923-940, 2003.

[5] R. E. Melchers and R. Jeffrey, "Early corrosion of mild steel in seawater," Corrosion Science, vol. 47, no. 7, pp. 1678-1693, 2005.

[6] C. Pillay and J. Lin, "The impact of additional nitrates in mild steel corrosion in a seawater/sediment system," Corrosion Science, vol. 80, pp. 416-426, 2014.

[7] T. Hemmingsen, F. Fusek, and E. Skavås, "Monitoring of the corrosion process on sulphide film formation with electrochemical and optical measurements," Electrochimica Acta, vol. 51, no. 14, pp. 2919-2925, 2006.

[8] E. B. Hansson, M. S. Odziemkowski, and R. W. Gillham, "Formation of poorly crystalline iron monosulfides: surface redox reactions on high purity iron, spectroelectrochemical studies," Corrosion Science, vol. 48, no. 11, pp. 3767-3783, 2006. 
[9] S. M. Abd El Haleem and E. E. Abd El Aal, "Electrochemical behaviour of iron in alkaline sulphide solutions," Corrosion Engineering Science and Technology, vol. 43, no. 2, pp. 173-178, 2008.

[10] W. Z. Shi, L. W. Tong, Y. Y. Chen, Z. Li, and K. Shen, "Experimental study on influence of corrosion on behavior of steel material and steel beams," Journal of Building Structures China, vol. 33, no. 7, pp. 53-60, 2012.

[11] L. Yue, The Research of Behavior and Effect and Mechanism of Rare Earths in Cu-P-RE Weathering Steel, vol. 26, Northeastern University, Boston, Mass, USA, 2006.

[12] E. Poorqasemi, O. Abootalebi, M. Peikari, and F. Haqdar, "Investigating accuracy of the Tafel extrapolation method in $\mathrm{HCl}$ solutions," Corrosion Science, vol. 51, no. 5, pp. 1043-1054, 2009.

[13] Q. L. Xie, W. M. Chen, and Q. Yang, "Influence of sulfur anions on corrosion of $16 \mathrm{mn}$ low-alloy steel in sulfide-containing bayer solutions," Corrosion, vol. 70, no. 8, pp. 842-849, 2014.

[14] P. E. Hazlewood, P. M. Singh, and J. S. Hsieh, "Corrosion behavior of carbon steels in sulfide-containing caustic solutions," Industrial and Engineering Chemistry Research, vol. 45, no. 23, pp. 7789-7794, 2006.

[15] H.-Z. Cao, J.-Y. Zhang, G.-Q. Zheng, and J.-G. Yuan, "Polarization behavior of carbon steel in sulfur-bearing solution," Corrosion \& Protection, vol. 23, no. 10, pp. 427-429, 2002.

[16] Z. M. Zhang, J. Q. Wang, E. H. Han et al., "Effects of surface condition on corrosion and stress corrosion cracking of alloy 690TT," Journal of Chinese Society for Corrosion and Protection, vol. 31, no. 6, pp. 441-445, 2011.

[17] X. Su, Z. X. Yin, and Y. F. Cheng, "Corrosion of 16Mn line pipe steel in a simulated soil solution and the implication on its longterm corrosion behavior," Journal of Materials Engineering and Performance, vol. 22, no. 2, pp. 498-504, 2013.

[18] M. A. Veloz and I. González, "Electrochemical study of carbon steel corrosion in buffered acetic acid solutions with chlorides and $\mathrm{H}_{2}$ S," Electrochimica Acta, vol. 48, no. 2, pp. 135-144, 2002.

[19] J. Y. Zou and D. T. Chin, "Anodic behavior of carbon steel in concentrated $\mathrm{NaOH}$ solutions," Electrochimica Acta, vol. 33, no. 4, pp. 477-485, 1998.

[20] B. He, C.-H. Lu, P.-J. Han, and X.-H. Bai, "Short-term electrochemical corrosion behavior of pipeline steel in saline sandy environments," Engineering Failure Analysis, vol. 59, pp. 410418, 2016.

[21] H. Liu, D. Xu, A. Q. Dao, G. Zhang, Y. Lv, and H. Liu, "Study of corrosion behavior and mechanism of carbon steel in the presence of Chlorella vulgaris," Corrosion Science, vol. 101, pp. 84-93, 2015.

[22] J. Kang, J. Li, K.-Y. Zhao, X. Bai, Q.-L. Yong, and J. Su, "Passivation behaviors of super martensitic stainless steel in weak acidic and weak alkaline $\mathrm{NaCl}$ solutions," Journal of Iron and Steel Research International, vol. 22, no. 12, pp. 1156-1163, 2015.

[23] J. B. Tan, X. Q. Wu, E.-H. Han, X. Q. Liu, X. L. Xu, and H. T. Sun, "The effect of dissolved oxygen on fatigue behavior of Alloy 690 steam generator tubes in borated and lithiated high temperature water," Corrosion Science, vol. 102, pp. 394-404, 2016.

[24] L. Jinlong, L. Tongxiang, W. Chen, and G. Ting, "Comparison of corrosion behavior between coarse grained and nano/ultrafine grained alloy 690," Applied Surface Science, vol. 360, pp. 403408, 2016.
[25] H. Luo, H. Su, C. Dong, K. Xiao, and X. Li, "Electrochemical and passivation behavior investigation of ferritic stainless steel in alkaline environment," Construction and Building Materials, vol. 96, pp. 502-507, 2015. 

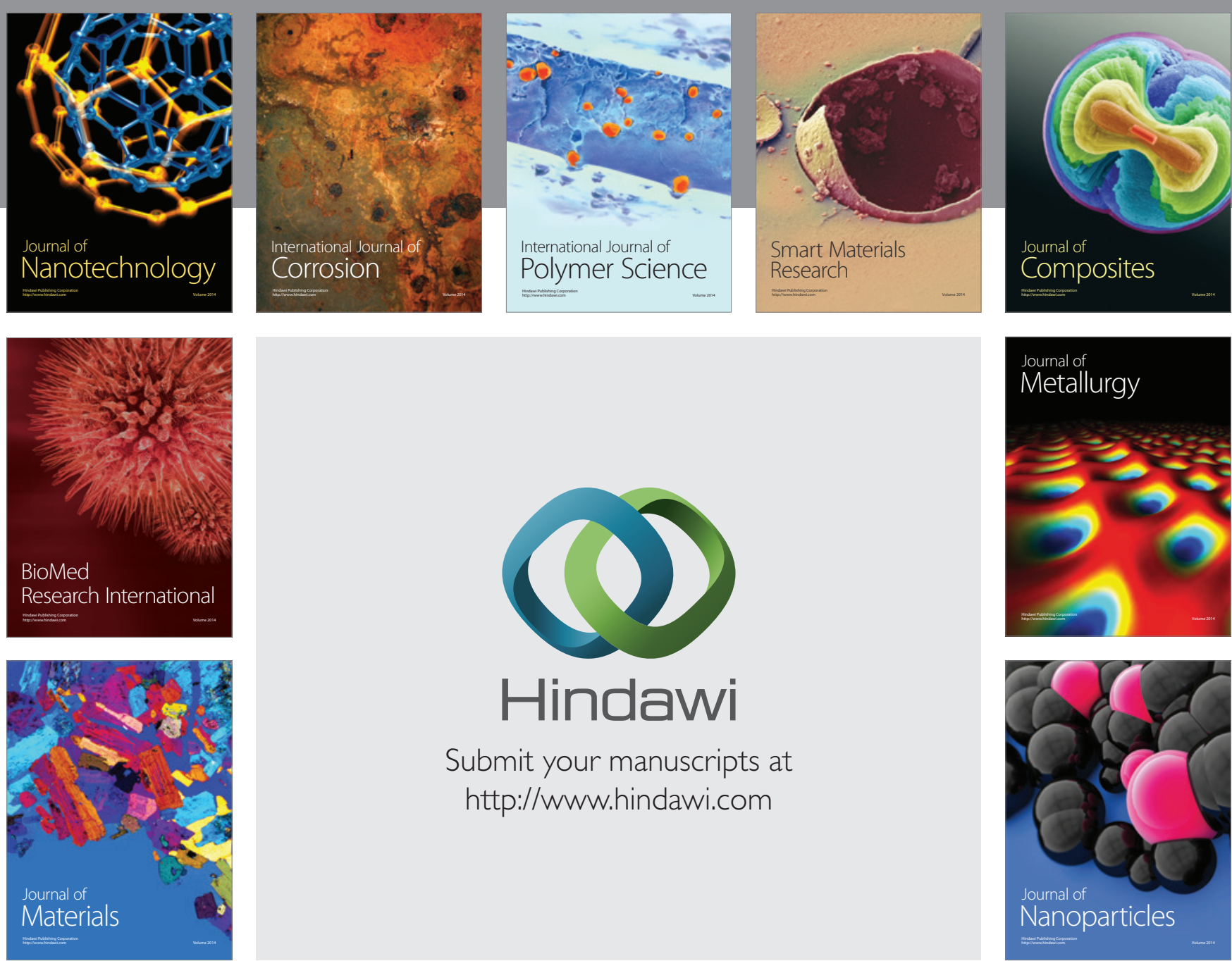

\section{Hindawi}

Submit your manuscripts at

http://www.hindawi.com

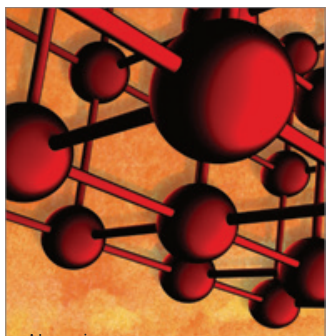

Materials Science and Engineering
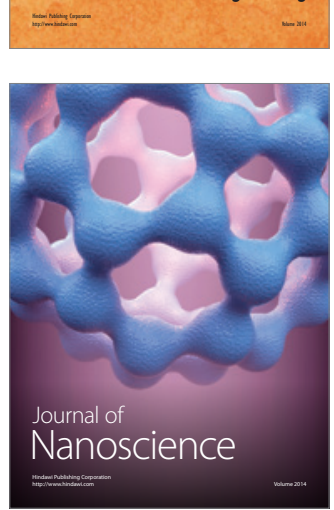
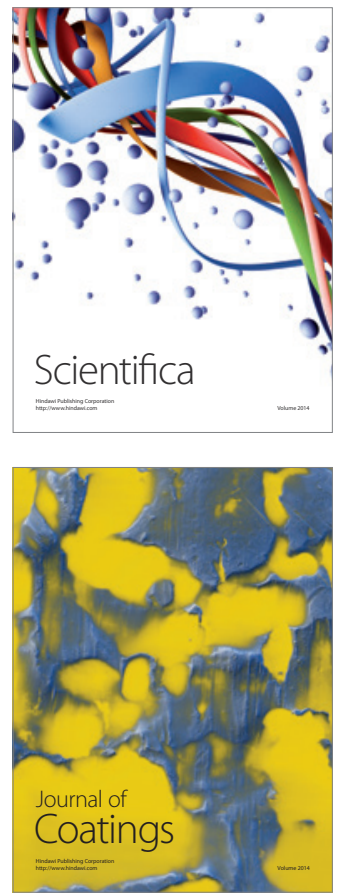
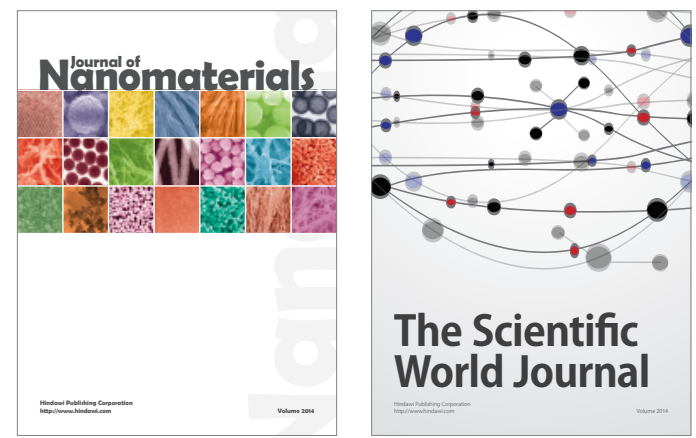

The Scientific World Journal
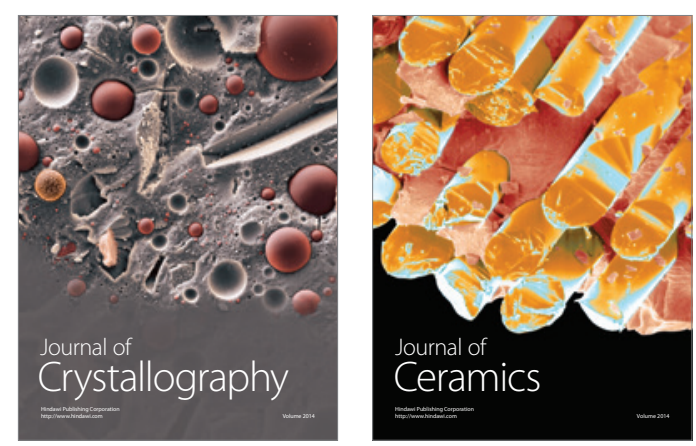
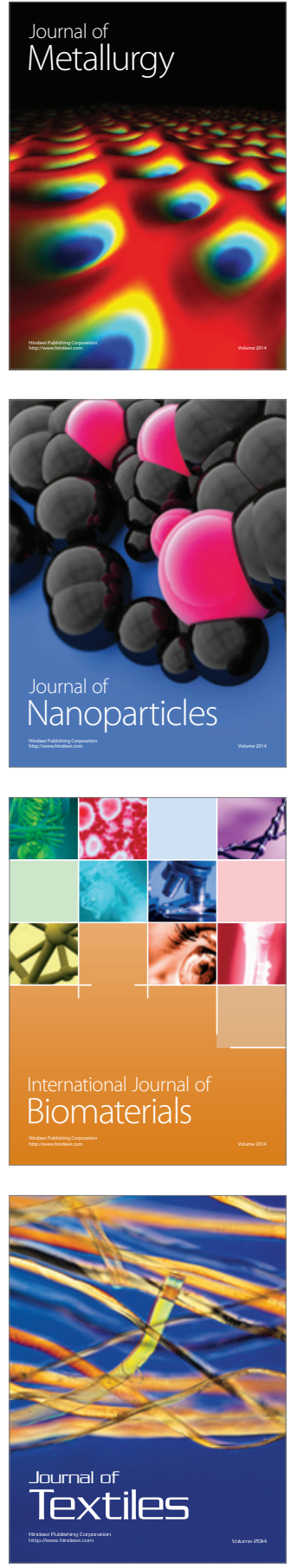